\title{
PUBLIC PERCEPTION OF OPTIMIZATION IN THE VILLAGE FUND ALLOCATION SUB DISTRICT Seyegan SLEMAN YEAR 2016
}

\author{
Saodatul Qhamariyah, Erni Zuhriyati \\ Government Science Program, \\ the University of Muhammadiyah Yogyakarta FISIP \\ saodatulqhamariya18@gmail.com
}

\begin{abstract}
Allocation of village funds is funds originating from the district / city budget Whose source is from the central and regional financial balance funds and then received by the Regency or City with a minimum amount of $10 \%$. In its management there is certainly a role for the community Involved. The public perception of the management of village fund allocation is urgently needed to assess the extent of the government's success in using the village's fund allocation. In this study aims to Determine the public perception of Village Fund Allocation Optimization in Seyegan District in 2016. Which in this year the budget allocation for village funds is among the third highest number in Sleman Regency. In this study Carried out by using a quantitative descriptive type of research, community perceptions roomates with numerical describes the data that has been Obtained in the field with the number of respondents 100 spread across five villages in Seyegan District. The results of this study indicate that the Community Perception of Village Fund Allocation Optimization in Seyegan District in 2016 shows an index value of 3.70, the which means that the management of village fund allocations in Seyegan District in 2016 is good. This is proven by the existence of better infrastructure, decreasing poverty rates and increasing community welfare by developing one of the potential of his village in the form of tourism villages and aquaculture.
\end{abstract}

Keywords: Community Perception, Optimization, and Village Fund Allocation 


\section{INTRODUCTION}

Rural and urban are the two lowest administrative unit under the district / city. He was given the rights of indigenous autonomy so it is a legal entity, while the village is a unit of government administration is an arm of the district / city. (Hanif Nurcholis: 2002). In the governance process of the village, village finance is very important in supporting the process of development and village administration. Finance of the village comes from local revenue, the budget, and the state budget. So every district or city government should allocate funds from its budget to the village. The allocation of village funds come from Budgets districts / cities where the source of the financial balance of central and local, and then accepted by the District or City with a total of at least $10 \%$. This was stated in the Minister of Interior of the Republic of Indonesia Number 113 of 2014 on the management of the Village Finance. Other than as mentioned in the Regulation, regulation fund allocation village has also been set in the decree Sleman District No. 6 of 2015 Section 3 states that one of the purposes of the allocation of village fund is to increase the distribution of development, prosperity, opportunities for participation and opportunities for rural communities as well as rural infrastructure development and community empowerment. One of these community empowerment can be done through the use of natural resources that could be developed well and managed so as to provide benefits to the community in the region.

In 2016 the District Seyegan among the regions with the highest fishing potential se Sleman. This is a great advantage for the people of the District Seyegan because of the potential of natural resources has a very high weight in determining the resource potential of the territory of a region with the proviso must be able to manage this potential in order to continue to rise. In addition to its natural resources, the District Seyegan also one of the Top District of third in the construction of educational facilities after Pakem and Depok. The number of educational facilities also tolerable let alone the construction of buildings for middle and upper schools. With their natural potential is certainly need for financing to develop this potential. The existence of the Village Fund Allocation should be able to develop the potential that continues to increase. In this year's budget Village Allocation Fund received by the District Seyegan is the third highest number after sub-district and sub-district Nganglik Paste.

With the potential possessed by the District Seyegan both in terms of aquaculture, the potential for some tourism in the area or other potential is expected to be a source of empowerment implementation. Therefore, the problem in this research is how the public perception towards the optimization of the Village Fund Allocation in District Seyegan $2016 "$ 


\section{LITERATURE REVIEW}

This study refers to some previous studies such as The first is a study conducted by Desmond Mahamurah, Mark Kaunang, Sarah Sambiran with the title "Village Fund Allocation Optimization To Improve Rural Development (studies in the village of the District Nahepese Mangatinu). From these results it can be seen that in the village Village Allocation Fund Nehepese still not optimal. This is due to the lack of implementation of community development programs in 2016. Though basically a division of the village fund allocation of $70 \%$ to be used in community development programs. And a study done Chandra Kusuma Putra, Ratih Nur Pratiwi, Suwondo with the title "Village Fund Allocation Management in Rural Community Empowerment" of the results of this research note that the use of Village Allocation Fund has not been used as its function. Because it was found that the budget for community empowerment is used for government operating costs and BPD. This happens due to lack of supervision by the public.

From several previous studies may be some similarities and differences with the research I would do. The equation is in this study were both about the process of management of village fund allocation. Then here is what distinguishes this study I would focus the object of his research on the public perception because society is more a feel for how the service or the management of the Village Fund Allocation which is carried by the village government.

\section{FRAMEWORK THEORY}

1. Public perception

Social perception is a process of interpretation, assessment and regulation sensory information about another person. Then What has been acquired, interpreted, or rated in the form of information that has been obtained through the neighborhood. So the object here is another person (Sarwono and Meinarno, 2009: 24). Then, in determining whether a perception certainly needed a subject that will give attention to the object in perceptions. Which in this study is the subject of society. Because people are the target of their allocation of village funds in an effort to improve and develop the human resources or natural resources. Therefore Walgito (1990: 54-55) mentions a number of indicators of community perceptions include:

a. Absorption, individuals and communities receive the object through the five senses, sight, hearing, smell, touch, and taste buds either simultaneously or not

b. Insight and understanding, stimulation of the brain that has been entered into the form of a picture or image that is then interpreted

c. Assessment, evaluation phase is influenced by the values, norms and rules that embrace every individual, therefore the assessment will be objective or individual. 
From some of the above theory can be deduced that the perception of a person's ratings or outlook on something he already knew directly or through an intermediary media. Then the indicators of public perception itself includes absorb, understand and comprehend and assess or evaluate.

\section{Optimizing}

Sons (in hamdalah, 2014: 41) also mentions Optimization is an action or actions to get the best results with any given situation, as well as the process for obtaining state or mimimum get the maximum value from a function. From some of the above theory, optimization can be interpreted as a way of efforts, processes and actions to be able to use the resources held in the aim to achieve a condition of the best, most desirable, most profitable in a boundaries and specific criteria.

In connection with this research, the indicators used are as mentioned in the Regulation No. 113 of 2014 concerning Financial Management of the Village. Which in Article 2 states that the financial management of the village should be done based on the principle -asas following:

1. Transparency is honesty and openness of information as possible for stakeholders to know every detail use of the budget of the village fund allocation

2. Accountable that accountability must be done by the village government for the management of village fund allocation

3. Participatory namely the participation and involvement of rural communities in deciding policy decisions village

4. Is orderly and disciplined budget that information was related to the adequacy of the funds obtained by the village government to cover all the expenses as well as the timeliness of the village used to carry out the development

Thus, the conclusion of the optimization is effort, process, method, and action to use resources owned in order to achieve the best conditions, most profitable and most desirable within certain limits and certain criteria.

\section{Allocation of village funds}

According to Law No. 06 of 2014 on the village, the village fund allocation are funds allocated by the government of district / city to the village that comes from the financial balance of central and local received by the district / city to fund all the programs of the village administration. The amount is at least $10 \%$ (ten percent) of the balance funds received by the district / city in the Budget Revenue and Expenditure after deduction of Special Allocation Fund.

The purpose of their allocation by Hanif Nurcholis village (2002) is as follows:

a. Tackling poverty and reduce poverty; 
b. Improve development planning and budgeting at the village and community empowerment;

c. Improving rural infrastructure development;

d. Improving the practice of religious values, social culture in order to realize social improvement;

e. Improving public peace and order;

f. Improve services to rural communities in the development of social and economic activities;

g. Encourage community self-reliance and mutual cooperation;

h. Raising rural incomes and rural communities through village-owned enterprises (BUMDesa)

The Basic Law relating to the management of the Village Fund Allocation of them (Haryati, 2015):

1. Government regulations in the country number 37 of 2007 on guidelines for the financial management of the village

2. Indonesian republic government regulation number 72 of 2005 on village

3. Sleman Regent Regulation No. 6 of 2015 on Village Fund Allocation

\section{RESEARCH METHODS}

a. Types of research

Type of this research is quantitative descriptive. The aim of this quantitative study is to determine the public perception of the optimization of the allocation of funds Seyegan village in the district of Sleman Regency Year 2016. This research uses descriptive quantitative research. Type a descriptive here to describe in detail related to the research focus is the public perception of the optimization of Village Allocation Fund in the District of Sleman Seyegan 2016.

b. Research sites

In doing research for information, the researchers chose research sites in the District Seyegan Sleman Yogyakarta Special Province.

c. Analysis unit

This research was conducted by researchers in the district of Sleman Seyegan because they want to know the public perception of the optimization of the Village Fund Allocation in the area.

d. The type of data

1. Primary data

According Silalahi (2012: 289) of primary data sources are often also referred to as first hand information that the original data source of the respondents. Primary data can also be a collection of actual data from an 
event that occurred. The primary data source is usually obtained from an individual, focus groups and one group of primary khusus.Data respondents in this study obtained from respondents by spreading questionnaires to people in the district of Sleman Seyegan.

2. Secondary Data

According Silalahi (2012: 291) or a secondary data is often referred to as second-hand information is a source of research data obtained through the medium of an intermediary or derived from the data that existed prior to the study conducted suadah. Secondary data sources include the form of articles, journals, archives organizations, articles in newspapers, reports, findings of the previous survey, the publication of the government, the information published or unpublished.

e. Population and Sample Collection Techniques

1. Population

The population in this study were all heads of families in the district of Sleman Seyegan amounting to 5 villages with a total population of 49 845

2. samples

According Sugiyono (2015: 118) The sample is part of the number and characteristics possessed by the population, when the population at large the study researchers may learn all there is in the population due to budget and time constraints. So researchers can use the sample. In the sampling there are several methods that can be used, but the researchers used a purposive sampling. According Sugiyono (2015: 124) Sampling is purposive sampling technique with a certain consideration. The authors in this study using the formula Slovin with sample size calculation, population and fault tolerance limit of $10 \%$ (error tolerance). The calculation is as follows:

$$
\begin{aligned}
& \mathrm{n}=\mathrm{N} /(1+\mathrm{N} \times \mathrm{e} 2) \\
& =49,845 / 1+49,845(102) \\
& =49,845 / 49,845(0.01)+1 \\
& =49,845 / 498.45+1 \\
& =49845 / 499.45 \\
& =99.79 \\
& =100
\end{aligned}
$$

f. Data collection technique

According Silalahi (2012: 291) dalah data collection methods in ways that are used in data collection of empirical 
phenomena. Data collection techniques used in this study were questionnaires and documentation

1. questionnaires

According Sugiyono (2013) questionnaire is one of the techniques of data collection is done by giving a few questions or statements in writing to the respondent. In practice, went to the field needs to be done to get the desired data because through this method requires direct contact between respondents and researchers. Questionnaires distributed focuses on people in some villages in the district of Sleman Seyegan. The scale used in this questionnaire is a Likert scale.

2. Documentation

According to Ridwan in the thesis Dimas Septian Riskiyanto (2017: 47), documentation is intended to obtain data directly from the study, includes books relevant legislation, activity reports, photographs, documentary films, the relevant data in the study. This documentation method to complete the data were not obtained by the prior art, namely by recording or copying materials in the form of a general overview of the District Seyegan that includes profiles, vision, mission, goals, organizational structure, facilities, and infrastructure as well as activity-supporting activities in terms of relating to the optimization of allocation of village funds.

g. Data Analysis Techniques

Analysts data is the most important part in the study, because the way the benefits of scientific analysis of the data would look, especially in problem solving research and the ultimate goal of a study. In the study researchers used a questionnaire to collect data from respondents. Questionnaires were used in the form of five-level scale (Likert).

The formula used in this study are as follows:

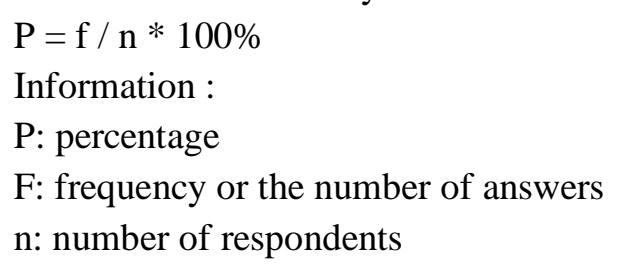

The technique of data analysis in this study using descriptive statistical techniques. Which descriptive ststistik technique according Sugiyono (2015) is a technique used in the events that can be measured quantitatively or can also be expressed by a number (scale, index, formula, and so on). Then to conclude that the data gained from the questionnaire using an index scale

h. Validity test 
Validity validity comes from the word that has meaning the extent to which the precision and accuracy of a measuring instrument in melakukam function of its size (Azwar 1986). Additionally validity is a measure that indicates that the measured variables really want variables studied by researchers (Cooper and Schindler, in Zulganef, 2006).

Meanwhile, according to Sugiharto and Sitinjak (2006), the validity associated with a variable measure what should be measured. The validity of the study states the degree of accuracy of the measuring instrument to the study measured the actual content. Validity test is a test that is used to indicate the extent of measuring instruments used in a measure what is being measured. Ghozali (2009) states that the validity of the test used to measure invalid or valid whether or not a questionnaire. A questionnaire considered valid if the questions in the questionnaire were able to reveal something that will be measured by the questionnaire.

i. test Reliability

Reliability comes from the word reliability. Definition of reliability (reliability) is the constancy of the measurement (Walizer, 1987). Sugiharto and Situnjak (2006) states that the reliability refers to an understanding that the instruments used in the study to obtain reliable information used as a means of data collection and to reveal the actual information field. Ghozali (2009) states that the reliability is a tool to measure a questionnaire which is an indicator of variables or constructs. A questionnaire said to be reliable or reliable if someone answers on the statement is consistent or stable over time. The reliability of a test refers to the degree of stability, consistency, predictability, and accuracy.

\section{DESCRIPTION OBJECT OF RESEARCH}

a. Profiles and sub-district layout Seyegan

Seyegan is a sub-district located in Sleman, Yogyakarta Special Province. Subdistrict Seyegan located in the southwest district of Sleman. The distance to the center of government sub-district Seyegan Sleman is $9 \mathrm{~km}$. Seyegan sub-district has an area of $26,12 \mathrm{~km} 2$. This district has a village 5 comprising Margoagung village, Margokaton, Margomulyo, Margoluwih, and Margodadi. Five villages of the District Seyegan has a number of 67 hamlets. (Quoted from the subdistrict Seyegan BPS 2016). The boundaries of the District Seyegan is the northern part bordering the District of Paste and the District of Sleman and to the west by District and Sub-District Minggir Tempel, the southern part is bordered by Godean, and the eastern part is bordered by District Mlati.

b. Population

1. Data Population by Sex Every Village 
As with previous years the number of residents in the District Seyegan increased. In 2016 the district population is 50831 inhabitants Seyegan consisting of 25343 men and 25488 women.

2. Population Data According to Education

Figures education and knowledge in the region will affect the community in developing the region and also in making decisions, including decisions in an effort to empower people in the District Seyegan as in the effort to develop the land and grow the business. The total population in the District Seyegan by Level of Education can be seen in the following table:

population data by level of education

\begin{tabular}{|l|c|c|}
\hline \multicolumn{1}{|c|}{ Information } & total & $\%$ \\
\hline No school & 8562 & 16.84 \\
\hline Not to End SD / MI & 5,970 & 11.74 \\
\hline Graduated SD / MI & 8889 & $17: 49$ \\
\hline SMP / MTS & 7263 & $14: 29$ \\
\hline SMA / SMK / MA & 16102 & 31.68 \\
\hline Diploma III III & 1,076 & 0796 \\
\hline $\begin{array}{l}\text { Academy / Dplm } \\
\text { /S.Mud }\end{array}$ & 2,402 & $2: 12$ \\
\hline Diploma IV / Strata I & 150 & 4.73 \\
\hline strata II & 12 & 0295 \\
\hline strata III & $\mathbf{5 0 8 3 1}$ & $\mathbf{1 0 0 . 0 0}$ \\
\hline TOTAL & & 0023 \\
\hline
\end{tabular}

Source: Central Bureau of Statistics Sleman 2016

From the table above it can be seen that the majority of the population in Sub Seyegan High School educated in the amount of 16 102 or $31.68 \%$. Then the elementary education population numbered 8889 , or $17.49 \%$. And the number of people without school numbered 8562 , or $16.84 \%$. And the highest educated populations Strata III amounted to 12 people or $0.023 \%$ of the total population in the District Seyegan.

c. Land condition

Of the total area in the district Seyegan Used by the majority as the yard and fields. Paddy soil used by farmers as a source of their 
Page 647-668. ISBN: 978-602-6 988-75-1

Web Jurnal Online: jurnal.unmuhjember.ac.id

By: Saodatul Qhamariyah; Erni Zuhriyati

Public Perception of Optimization in The Village Fund Allocation Sub District Seyegan

Sleman Year 2016

livelihood. The details of the use of land in the District Seyegan can be seen in the following table.

Land Uses in District Seyegan

\begin{tabular}{|l|c|c|c|c|c|}
\hline \multicolumn{1}{|c|}{ Village } & Land Rice & $\begin{array}{c}\text { building } \\
\text { courtyard }\end{array}$ & Dry soil & more & total \\
\hline Margoluwih & 299.23 & 151.30 & 3.64 & 45.83 & 500 \\
\hline Margodadi & 330.94 & 175.32 & 39.46 & 65.28 & 611 \\
\hline Margomulyo & 259.23 & 227.96 & 0.91 & 30.89 & 518.99 \\
\hline Margoagung & 279.81 & 194.80 & 2.41 & 40.98 & 518 \\
\hline Margokaton & 319.43 & 143.47 & 0,00 & 52.10 & 515 \\
\hline TOTAL & $\mathbf{1 4 8 8 . 6 4}$ & $\mathbf{8 9 2 . 8 5}$ & $\mathbf{4 6 . 4 2}$ & $\mathbf{2 3 5 . 0 8}$ & $\mathbf{2 6 6 2 . 9 9}$ \\
\hline
\end{tabular}

Source: Central Bureau of Statistics Sleman 2016

Based on the above table, it can be seen that the use of land in the District of Seyegan most widely used mainly as a wetland number of 1488.99 or equal to $54.40 \%$. Then it is also used as a building yard number 892.85 , or $33.52 \%$, is also used as a dry land area 46.42 or $1.75 \%$ and the latter is used as common land equal to the number of 235.08 or $8.85 \%$.

\section{d. Government}

Subdistrict camat Seyegan a working area as an area led by sub-district which is under and responsible to the Regent through the regional secretary. A district head has the task of coordinating penyelenggaraaan general government, public services, community development, and carry out some government affairs has been mandated by the Regent.

e. financial village

According to the Regulation No. 113 of 2014 Financial village are all rights and obligations of the village that can be valued in money and everything in the form of money and goods related to the implementation of the rights and obligations of the village. The village is the overall financial management activities including planning, implementation, administration, reporting, and financial accountability village.

1. Village fund

Village fund is a fund of the State Budget earmarked for the village and transferred through the budget Regency / City every year, to finance the implementation of the authority of the village is based on the rights of the proposal, and the local authority of the village scale. Below is the number of 
Page 647-668. ISBN: 978-602-6 988-75-1

Web Jurnal Online: jurnal.unmuhjember.ac.id

By: Saodatul Qhamariyah; Erni Zuhriyati

Public Perception of Optimization in The Village Fund Allocation Sub District Seyegan

Sleman Year 2016

Village Fund that was obtained in the District Seyegan already detailed each village.

Table amount of funds sub-district village Seyegan years 2015-2017

\begin{tabular}{|c|l|c|c|c|}
\hline No. & Village name & 2015 & 2016 & 2017 \\
\hline 1 & Margoluwih & 333143000 & 768560000 & 987306000 \\
\hline 2 & Margodadi & 330632000 & 755696000 & 970388000 \\
\hline 3 & Margomulyo & 342906000 & 818579000 & 1.053086 billion \\
\hline 4 & Margokaton & 328378000 & 744151000 & 955205000 \\
\hline 5 & Margoagung & 343850000 & 823414000 & 1.059445 billion \\
\hline & TOTAL & $\begin{array}{c}\mathbf{1 . 6 7 8 9 0 9} \\
\text { billion }\end{array}$ & $\mathbf{3 . 9 1 0 4}$ billion & $\mathbf{5 . 0 2 5 4 3}$ billion \\
\hline
\end{tabular}

Source: Bappeda Sleman

From the table it can be seen bahwsanya Village Fund budget amounts each year has increased significantly. In 2015, the number of whole sub-district Village Fund budget amounted to 1.678909 billion Seyegan then in 2016 increased the overall amount of 3.9104 billion and in 2017 with the number 5.02543 billion.

2. Allocation of village funds

The allocation of funds is income rural village that has been obtained from the Government of Regency / City funded by central and local financial balance which has been accepted by the District / Municipal minimum of $10 \%$ for the village. The DAPT usage is intended to increase the empowerment of communities, as well as to enhance the progress of a region both in terms of economy, health, education and also in social and cultural fields.

Thus the number of village fund allocation is adjusted to the conditions in the area of each region. The following tables represent the number of Village Allocation Fund in District Seyegan of the year 2015-2017

Table 9 Number of Allocation Fund Village Sub Seyegan years 2015-2017

\begin{tabular}{|c|c|c|c|c|}
\hline No. & Village name & 2015 & 2016 & 2017 \\
\hline 1 & Margoluwih & 1193463379 & $\begin{array}{c}1.250276 \\
\text { billion }\end{array}$ & $\begin{array}{c}1.297776 \\
\text { billion }\end{array}$ \\
\hline 2 & Margodadi & 1119284844 & $\begin{array}{c}1.162978 \\
\text { billion }\end{array}$ & 1.19661 billion \\
\hline 3 & Margomulyo & 960338155 & 999707000 & 1.282733 \\
\hline
\end{tabular}


Page 647-668. ISBN: 978-602-6 988-75-1

Web Jurnal Online: jurnal.unmuhjember.ac.id

By: Saodatul Qhamariyah; Erni Zuhriyati

Public Perception of Optimization in The Village Fund Allocation Sub District Seyegan

Sleman Year 2016

\begin{tabular}{|c|c|c|c|c|}
\hline & & & & billion \\
\hline 4 & Margokaton & 1195661064 & $\begin{array}{c}1.258239 \\
\text { billion }\end{array}$ & $\begin{array}{c}1.042662 \\
\text { billion }\end{array}$ \\
\hline 5 & Margoagung & 1133205808 & $\begin{array}{c}1.186646 \\
\text { billion }\end{array}$ & $\begin{array}{c}1.223056 \\
\text { billion }\end{array}$ \\
\hline & TOTAL & $\mathbf{5 6 0 1 9 5 3 2 5 0}$ & $\begin{array}{c}\mathbf{5 . 8 5 7 8 4 6} \\
\text { billion }\end{array}$ & $\begin{array}{c}\mathbf{6 . 0 4 2 8 3 7} \\
\text { billion }\end{array}$ \\
\hline
\end{tabular}

Source: Bappeda Sleman

From the table it can be seen that the number of Village Allocation Fund as well as the Village Fund has increased every year. Despite the increase from 2015 to 2016 is not too much but enough peningktannya next year. The villages get aloakasi budget funds smallest village in 2016 is Margomulyo village. And the village is the most widely got Margokaton village.

3. The use of the allocation of the village

Use of Village Allocation Fund which has been set in Sleman Perbub No. 6 of 2016 on Village Fund Allocation. which use the village fund allocation should be in accordance with what has been stipulated in the Perbub ie $30 \%$ for operational expenditure of government and $70 \%$ for development and community empowerment. As for the use of funds allocated Seyegan village in the district in 2016 can be seen in the table below:

Use of the Village Fund Allocation Table 2016

\begin{tabular}{|l|l|l|}
\hline No. & Use of the Village Fund Allocation & percentage of ADD \\
\hline 1 & $\begin{array}{l}\text { Social assistance and social finance } \\
\text { Village }\end{array}$ & $25 \%$ \\
\hline 2 & Rural Infrastructure Development & $40 \%$ \\
\hline 3 & \begin{tabular}{l} 
Operational expenditure Village \\
\hline 4
\end{tabular} & $\begin{array}{l}\text { Fixed Income Head of Village and the } \\
\text { Village and BPD }\end{array}$ \\
\hline & number Percentage & $15 \%$ \\
\hline
\end{tabular}

Source: BPS District of Seyegan 2016

From the table above it can be seen that the total budget allocation of villages with the highest percentage used for infrastructure development in the 
District Seyegan with the number of $40 \%$. The development of infrastructure in Sub Seyegan more focused on road improvements and constructing a gate in tiapeach village. Subsequently used for Operational Expenditure village some $30 \%$. To help finance the social and civic village some $25 \%$. This social assistance must help people with low economic level to open a business or to develop the potential of the village in the district Seyegan. And the latter is used for fixed income village head, village and some $15 \%$ of BPD.

\section{RESULTS AND DISCUSSION}

\section{A. Characteristics of Respondents Research}

People who fill in the questionnaire or the respondents in this study were people who settled in the District Seyegan a way selected randomly in five villages in the district Seyegan. Based on data gathered in the field, there are three characteristics of respondents listed dai in the discussion of this study, of which is based on gender, profession and age. Here is an overview of the data characteristics of respondents in this study:

\section{Respondent characteristics by Sex}

Table Characteristics of Respondents by type Gender

\begin{tabular}{|c|c|c|c|}
\hline No. & Gender & total & percentage \\
\hline 1 & Man & 57 & $57 \%$ \\
\hline 2 & woman & 43 & $43 \%$ \\
\hline & Total & 100 & $100 \%$ \\
\hline
\end{tabular}

Source: Questionnaire

Based on the data that has been presented above, of the 100 respondents who have already filled out the questionnaire, composed of $57 \%$ men and $43 \%$ women. Thus the respondents in this study is dominated by the respondent with the male gender. 
Page 647-668. ISBN: 978-602-6 988-75-1

Web Jurnal Online: jurnal.unmuhjember.ac.id

By: Saodatul Qhamariyah; Erni Zuhriyati

Public Perception of Optimization in The Village Fund Allocation Sub District Seyegan

Sleman Year 2016

\section{Characteristics of Respondents by Profession}

Table characteristics of Respondents by Profession

\begin{tabular}{|c|l|c|c|}
\hline No. & \multicolumn{1}{|c|}{ type Profession } & total & percentage \\
\hline 1 & Private employees & 13 & $13 \%$ \\
\hline 2 & Student / student & 30 & $30 \%$ \\
\hline 3 & PNS & 15 & $15 \%$ \\
\hline 4 & Teacher & 7 & $12 \%$ \\
\hline 5 & entrepreneurial $\quad 23$ & $7 \%$ \\
\hline 6 & $\begin{array}{l}\text { Others (the Village, Farmers, } \\
\text { Workers, Housewife, Self, } \\
\text { Nurses, and Artisan Center) }\end{array}$ & 100 & $100 \%$ \\
\hline & \multicolumn{1}{|c|}{ TOTAL } \\
\hline
\end{tabular}

Source: Questionnaire

According to the table above, it can be seen that in this study the respondents work is divided into six categories. Namely Private Employees, Students / Student, civil servants, teachers, Entrepreneur, and others (the Village, Farmers, Workers, Housewife, Self, Nurses, and Artisan Center).

Works Private Employees has a percentage of 13\%, employment Student / Student has a percentage of $30 \%$, the work of civil servants has a percentage of $15 \%$, a teacher's job has a percentage of $12 \%$, employment Entrepreneurial has a percentage of $7 \%$ and the latter is the work of others which is a combination of various jobs have prosentaae $23 \%$.

3. Characteristics of Respondents by Age

Table

Characteristics of Respondents by Age

\begin{tabular}{|c|c|c|c|}
\hline No. & Age & total & percentage \\
\hline 1 & $16-25$ Years & 16 & $16 \%$ \\
\hline 2 & $26-35$ Years & 28 & $28 \%$ \\
\hline 3 & $36-45$ Years & 23 & $23 \%$ \\
\hline 4 & $46-55$ Years & 16 & $16 \%$ \\
\hline 5 & $56-65$ Years & 8 & $8 \%$ \\
\hline & TOTAL & 100 & $100 \%$ \\
\hline
\end{tabular}

Source: Questionnaire 
Based on data gathered in the field, the majority of respondents are at intervals of $26-35$ years of age with a percentage of $28 \%$. Then for respondents with $16-25$ year age group the percentage amount is $25 \%$. And the $36-45$ year age group the percentage amount is $23 \%$. Furthermore, for the group $46-55$ years has a percentage of $16 \%$. And last for ages 56-65 years had the lowest percentage of $8 \%$.

\section{B. Discussion on Public Perception Of Village Fund Allocation Optimization in District Seyegan 2016}

Based on data gathered in the field, then the following will be presented the data according to the indicators in the preparation of the study questionnaire. Where the indicators used in preparing the questionnaire question consists of three indicators, including indicators of public perception that includes receive, understand and assess. Then indicator Optimization which includes transparency, accountable, participatory and done tongue and in siplin budget. Furthermore, last indicator is an indicator of the Village Fund Allocation is overcome and reduce poverty, improve development planning and budgeting at the village and community development, rural infrastructure development, improve the practice of religious values, social culture in order to realize the improvement of social,

1. Public perception

Perception has a very important position as an input in the process of implementation and management of a system in a intansi either large or small institutions. Likewise, in a system of government either at central level or regional level. The perception of the community in particular can be used as an evaluation of the policies that have been implemented by the government as the executive coordinator of the program that has been planned. Their allocation of village funds are expected to be able to increase the good progress in terms of development or in terms of community empowerment. Therefore, every village will get help villages in the allocation of funds budgeted by the government according to population and condition of the region and its natural resources.

Indicators of public perception includes the receive, understand and evaluate and obtained the final results of the public perception indicators with the number of questions 7 about the obtained final index number of 3.49, which indicates that the public perception is related to the allocation of village funds were already good. The majority of people in the District Seyegan already understand that there is a budget provided by the government in the form of budget allocations budgeted village each year by taking into account several criteria in determining the amount that the number of inhabitants, the village poverty rate, area of the village and the level of difficulty in terms of geography. But here there are some groups of people who do not fully understand the function and purpose of the allocation of village funds this is due to lack of 
experience and lack of public interest to know things related to the allocation of village funds. The results were obtained data from question number 1 through 7 can be seen in the following table:

Table

Public perception towards their

Village Allocation Fund budget in the District Seyegan

\begin{tabular}{|c|l|c|c|c|c|c|c|c|}
\hline \multirow{2}{*}{ No. } & \multirow{3}{*}{ alternative Answers } & \multicolumn{9}{|c|}{ answer } \\
\cline { 3 - 9 } & & $\mathbf{1}$ & $\mathbf{2}$ & $\mathbf{3}$ & $\mathbf{4}$ & $\mathbf{5}$ & $\mathbf{6}$ & $\mathbf{7}$ \\
\hline 1 & Strongly Disagree & 0 & 0 & 0 & 1 & 2 & 1 & 0 \\
\hline 2 & Disagree & 10 & 17 & 18 & 8 & 2 & 9 & 4 \\
\hline 3 & quite Agree & 46 & 36 & 30 & 35 & 38 & 38 & 37 \\
\hline 4 & Agree & 38 & 45 & 48 & 52 & 48 & 44 & 42 \\
\hline 5 & Strongly agree & 6 & 2 & 4 & 4 & 10 & 8 & 17 \\
\hline & TOTAL & $\mathbf{1 0 0}$ & $\mathbf{1 0 0}$ & $\mathbf{1 0 0}$ & $\mathbf{1 0 0}$ & $\mathbf{1 0 0}$ & $\mathbf{1 0 0}$ & $\mathbf{1 0 0}$ \\
\hline
\end{tabular}

Source: Questionnaire Question Number 1-7

\section{Optimizing}

In allocating the budget, of course there are some important points that can be used as a benchmark to improve the allocation system more effective and efficient. These benchmarks include transparency, accountable, participatory, is orderly and disciplined budget. Below is data from studies using these four points to measure the extent of the optimization of allocation of funds to optimize Seyegan.Indikator village in the district in this study include transparency, accountability, participation, timely and budgetary discipline.

Thus, data from the questions and answers of respondents from number 8 to number 17, the overall index is 3.70 in both categories. This means that the optimization of the allocation of funds Seyegan village in the district is good or optimized. This occurs because of the good cooperation between the government and communities. In preparing the plan of government programs really adjusting to the situation and the needs required in the region. Suppose that in the construction of road infrastructure has been quite good so far. Also in terms of reducing poverty in the region to provide guidance to the public government in the economy by way of productive economic development activities as much as four times a year. 
Page 647-668. ISBN: 978-602-6 988-75-1

Web Jurnal Online: jurnal.unmuhjember.ac.id

By: Saodatul Qhamariyah; Erni Zuhriyati

Public Perception of Optimization in The Village Fund Allocation Sub District Seyegan

Sleman Year 2016

Table Village Fund Allocation Optimization level in District Seyegan 2016

\begin{tabular}{|c|l|l|l|l|l|l|l|l|l|l|l|}
\hline \multirow{2}{*}{ No. } & alternative \\
answers & & \multicolumn{10}{|c|}{ frequency response } \\
\cline { 3 - 14 } & 8 & 9 & 10 & 11 & 12 & 13 & 14 & 15 & 16 & 17 \\
\hline 1 & $\begin{array}{l}\text { Strongly } \\
\text { Disagree }\end{array}$ & 0 & 0 & 1 & 0 & 0 & 0 & 0 & 0 & 1 & 1 \\
\hline 2 & Disagree & 14 & 2 & 5 & 4 & 5 & 3 & 3 & 3 & 11 & 6 \\
\hline 3 & quite agree & 26 & 30 & 27 & 38 & 31 & 36 & 38 & 44 & 38 & 37 \\
\hline 4 & Agree & 40 & 50 & 45 & 31 & 52 & 44 & 42 & 41 & 42 & 50 \\
\hline 5 & $\begin{array}{l}\text { Strongly } \\
\text { agree }\end{array}$ & 20 & 18 & 22 & 27 & 12 & 17 & 17 & 12 & 8 & 6 \\
\hline & Total & 100 & 100 & 100 & 100 & 100 & 100 & 100 & 100 & 100 & 100 \\
\hline
\end{tabular}

Source: Questionnaire

3. Allocation of village funds

Based on data from number 18 to 25 in obtaining the total index number of 3.73 with both categories. That is the function of the allocation of funds Seyegan village in the district is good because it has increased quite clear both in terms of poverty reduction, improvement of infrastructure development, community empowerment. It is to be increased again so that the poverty rate in the district who previously predicate Seyegan highest number of poor households can be minimized annually. Not only is it in the form of community development activities also need to be maintained even if it needs to be improved in terms of both the farm or in terms of other land for example in the development of one of the sights in one of the villages in the district Seyegan. This is done so that the sub-district Seyegan able to compete with other sub-districts of sehngga not be lagging regions.

Table Village Fund Allocation Function in District Seyegan 2016

\begin{tabular}{|l|l|l|l|l|l|l|l|l|l|}
\hline \multirow{2}{*}{ No. } & \multirow{2}{*}{$\begin{array}{l}\text { alternative } \\
\text { Answers }\end{array}$} & 18 & 19 & 20 & 21 & 22 & 23 & 24 & 25 \\
\cline { 2 - 11 } & $\begin{array}{l}\text { Strongly } \\
\text { Disagree } \\
2\end{array}$ & 0 & 0 & 0 & 0 & 0 & 0 & 0 & 0 \\
\hline 3 & Disagree & 2 & 2 & 2 & 4 & 7 & 2 & 0 & 1 \\
\hline 4 & quite Agree & 39 & 36 & 34 & 35 & 35 & 33 & 40 & 33 \\
\hline 5 & $\begin{array}{l}\text { Agree } \\
\text { Strongly } \\
\text { agree }\end{array}$ & 44 & 43 & 46 & 47 & 48 & 53 & 46 & 54 \\
\hline & Total & 15 & 19 & 18 & 14 & 10 & 12 & 14 & 12 \\
\hline
\end{tabular}

Source: Questionnaire 


\section{CONCLUSION}

From the research that has been done by distributing questionnaires to 100 respondents in five villages in the district of Sleman Seyegan to obtain the public perception of the Village Fund Allocation Optimization in District Seyegan in 2016, namely in the village Margodadi, Margoagung, Margomulyo, Margokaton, and Margoluwih. The characteristics of the respondents in this study is based on age, sex and occupation.

Public perception to accept, understand and evaluate the budget allocation of the village and planned programs gain index value of 3.49 with both categories. This means that people in the District Seyegan many who receive a budget allocation of funds either directly village they get or indirectly. Many of them also understand the intent and purpose of the allocation of funds this village, and they also took part in an evaluation of the programs that have been carried out for improvement in subsequent years.

Then associated with the optimization of the allocation of funds obtained Seyegan village in the district total index value of 3.70 with both categories. This means that the management of funds allocated Seyegan villages in the district were optimal. It draws on several criteria such as transparency, accountability, participatory, orderly and disciplined budget. Manage the allocation of funds Seyegan village in the district is already quite good. Because of the good cooperation between the government and communities. Society is also involved in deciding the programs that have been planned and then implemented in the next year. Not only from the public Pemerintahpun required to account for the use of the budget allocation of village funds. this can be in the form of a report.

Then the last is the public perception of the implementation of the village fund allocation function index value of 3.73 was obtained with both categories. This means that the management of funds allocated villages in the district Seyegan been able to provide a better improvement as well as in terms of poverty were quite high in 2016 but the following year in Kecamtan Seyegan poverty rate has begun to decline. Besides the construction of infrastructure in Sub Seyegan is good enough as roadwork in the area of the highway or to remote corners of the village and the construction of the gate. 
Page 647-668. ISBN: 978-602-6 988-75-1

Web Jurnal Online: jurnal.unmuhjember.ac.id

By: Saodatul Qhamariyah; Erni Zuhriyati

Public Perception of Optimization in The Village Fund Allocation Sub District Seyegan

Sleman Year 2016

\section{SUGGESTION}

After this research, the authors intend to give advice that hopefully can be useful for government agencies or the public as well as for further research. Suggestions authors are as follows:

1. For Government Institutions

The government needs to conduct socialization about village finances and penggunannya.Adanya understanding in the allocation of village funds still need to be improved because there are still some groups of people who do not understand the function of the allocation of village funds. this so that the whole community can also participate in managing the allocation of village funds that have been in anggarakan by the government each year.

2. For Further Research

Further research is expected to examine many more sources and references related to the public perception of the ADD order to optimize research results can be better and more complete. 
Page 647-668. ISBN: 978-602-6 988-75-1

Web Jurnal Online: jurnal.unmuhjember.ac.id

By: Saodatul Qhamariyah; Erni Zuhriyati

Public Perception of Optimization in The Village Fund Allocation Sub District Seyegan

Sleman Year 2016

\section{BIBLIOGRAPHY}

\section{Book}

Alex Sobur. (2003). General Psychology. Bandung: Pustaka Setia.

Ben Walgito. (1991). Psych Umum. Yogyakarta: Andi Offset.

Ben, Walgito. 2002. Introduction to General Psychology. Publisher Andi Yogyakarta

Nurcholish, Hanif. 2002. Growth And The Governance of the village. Publisher. Jakarta.

Sarwono, Sarlito Eko W. \& A. Meinarno. (2009). Social Psychology. Jakarta: Publisher Salemba Humanika

Silalahi, Ulber.2012. Methods of Social Research and education. Bandung. PT Refika Aditama

Sugiyono, 2013. Research Methods Quantitative, qualitative, and R and D. Alfabeta. duo

\section{Journals}

Akhmad Fauzy and Anggara Setyabawana Son. (2015). Mapping the Village Potential locations in Sleman Tourism Year 2015. Journal of Innovation and Entrepreneurship. UII Yogyakarta

Arif Sofianto, (2017). Contribution to the Village Fund Development and Community Empowerment in Kebumen and Pekalongan.Regional Development Planning Board (Bappeda) Central Java Province. Jl. Pemuda No. 127-133 Semarang50132

Chandra Kusuma Putra, RN (2014). MANAGEMENT FUND ALLOCATION IN EMPOWERING RURAL VILLAGE (Studies in Rural Wonorejo Singosari Malang). Journal of Public Administration. Brawijawaya University. Poor.

Davis Budi Purnama and Hendy Widiastoeti. (2016). Internal Audit Management Information Systems Accounting Village Allocation Fund To Assess Performance Accountability village. Economic and Bisnis.Universitas Journal August 17, 1945 Surabaya.

Dwi Febri Arifiyanto and Taufik Kurrohman. (2014). Village Allocation Funds Management Accountability in Jember. Journal of Accounting and Finance Research, 2 (3), 2014.473 to 485

Justita Dura. (2016). Effect of the Financial Management Accountability Village Allocation Fund (ADD), Rural Policy and Institutional Village Against Public Welfare.JIBEKA Journal Volume 10 Number August 1, 2016: 26-32 
By: Saodatul Qhamariyah; Erni Zuhriyati

Public Perception of Optimization in The Village Fund Allocation Sub District Seyegan

Sleman Year 2016

Mahamurah, Desmond et al. 2017AOLOKASI OPTIMIZATION IN IMPROVING DEVELOPMENT FUND VILLAGE VILLAGE (Studies in the village of the District Nahepese Manganitu)

Noerma Alifahrani Bahtiar. (2017).Public Participation in Supervision Village Fund Allocation Program (ADD) in the village of Panjunan, Sukodono subdistrict, Sidoarjo. Journals Public Administration, Social and Political Science, University of Airlangga

Paul Israwan Setyoko. Accountability Financial Administration Village Fund Allocation Program.Master of Administrative Sciences Graduate Program UnSoed

Siti Ainul Wida, Djoko Supatmoko and Taufiqurrahman. Management Accountability Village Fund Allocation (ADD) on the Villages Rogojampi District of Banyuwangi.Faculty of Economics. University of Jember.

Teguh Riyanto. (2015). Financial Accountability in the Management of Village Allocation Fund (ADD) in the Office of the District Rural South Perangat Marangkayu Regency. Journal of Public Administration, 2015.3 (1) 119-130

Yuni Kurniasih, Hardi Warsono, and Budi Puspo Priyadi, (2018), Village Fund Allocation Policy Implementation in the village of Tegal Margasari. Tata Journal STIA Million Mataram.

Zuhrizal Fadly. Optimizing the Role of the District In the village of Financial Management. Faculty of Social and Political Sciences, University of Teuku Umar

Zulfan Nahruddin. (2014). Accountability and Transparency Village Allocation Fund Management in the village of Pao-Pao District of Tanete Rillau Barru.Governance Studies Program Faculty of Social and Political Sciences .Universitas Makassar Muhammadiyah.

Zulham Afandi. Village Fund Allocation Management (ADD) in 2013 in the village of the District Mekarsari Merbau Meranti Islands District. FISIP Riau University, Campus Bina Widya

\section{Essay}

Azizah, Rosfa N. (2017). Optimization Strategies Through the Rural Infrastructure Development of Rural Community Empowerment Program in Economic Perspective of Economic and Business Islam.Fakultas Islam. UIN Raden Intan Lampung.

Azwardi, Sakanto. (2017) Effectiveness of the Village Fund Allocation And Poverty In South Sumatra province. Thesis Faculty of Economics, University of Sriwijaya Palembang. 
Page 647-668. ISBN: 978-602-6 988-75-1

Web Jurnal Online: jurnal.unmuhjember.ac.id

By: Saodatul Qhamariyah; Erni Zuhriyati

Public Perception of Optimization in The Village Fund Allocation Sub District Seyegan

Sleman Year 2016

Dimas, Septian. (2017). Public Perception Of Ponorogo district leader in combating corruption in Ponorogo period 2010-2015. Thesis, University of Muhammadiyah Yogyakarta

Hamdalah, A. (2014). Optimizing System PT BRI Syariah Mudharabah In Pekanbaru. UIN theses SUSKA RIAU

Haryati, S. (2015). Implementation of the Village Fund Allocation Based Meranti Islands District Regulation No. 16 of 2011 Concerning Rural Finance (Studies In Desa Tasik Putri Puyu Mengkirau District of Kepulauan Meranti) (Doctoral Disertation, State Islamic University Syarif Kasim Sultan Riau).

Setiabudi H, Didiek. (2010). Village Allocation Funds Distribution Effectiveness In four villages in Karangasem Bali Province. Faculty of Economics, Master of Planning and Public Policy. Jakarta

Wida, SA (2016). Management Accountability Village Allocation Fund (AAD) in the villages of the District Rogojampi Banyuwangi

Wulandari, Sri S. (2017). Analysis Capabilities In the village government of the ADD Management in the village Margolembo Mangkutana Luwu Timur subdistrict. Faculty of Social Science and Political Science. Hasanuddin University, Makassar.

Law

1945

Act No. 6 of 2014 About the village

Regulation No. 113 of 2014 About the village of Financial Management

Regulation No. 37 of 2007 on Guidelines for Rural Financial Management

PP of the Republic of Indonesia Number 72 Year 2005 About the village

Sleman Regent Regulation No. 6 of 2005 on Village Fund Allocation

District of Seyegan Year Strategic Plan 2016-2021

Internet

www.Slemankab.go.id (Accessed on October 15, 2018 at 21:30) 